\title{
Genetic variability in morpho-agronomic traits of various accessions of Vigna subterranea (L.) Verdc.
}

\author{
Maruf Olaide YEKEEN ${ }^{1,2}$, Hafsoh Olajumoke SHAIB-RAHIM ${ }^{3}$, Joy OLABODE ${ }^{3}$
}

Received June 09, 2020; accepted June 17, 2020.

Delo je prispelo 09. junija 2020, sprejeto 17. junija 2020.

Genetic variability in morpho-agronomic traits of various accessions of Vigna subterranea (L.) Verdc.

Abstract: Vigna subterranea is an indigenous African legume widely cultivated across the continent. It is a highly diverse crop exhibiting diversity in morpho-agronomic characteristics. This genetic diversity is also crucial for crop improvement as it determines which breeding strategy/ methodology to utilize in its improvement. The study evaluated the diversity in morpho-agronomic characteristics of different accessions of Bambara groundnut. 'TVSu596' exhibited the highest germination percentage (100\%) and shortest days to $50 \%$ flowering (40 days) while 'TVSu11' had the highest number of leaves (146). Qualitative evaluation revealed the diversity existing in their morphological characteristics. Elemental analysis showed the accessions are rich in mineral elements and exhibit diversity. Principal component analysis revealed $83.37 \%$ of total variations in morphological and yield traits by the first three principal axes. Traits such as number of leaves, petiole length, and days to $50 \%$ flowering furnish most of the variations. Cluster analysis revealed the accessions clustered into 4 groups. These accessions are therefore recommended for utilization in development of improved cultivars or early-maturing varieties

Key words: Vigna subterranea; Bambara groundnut; genetic variation; morpho-agronomic analysis; chemical analysis
Genetska raznolikost in morfološko-agronomske lastnosti različnih akcesij bambare (Vigna subterranea (L.) Verdc.)

Izvleček: Bambara (Vigna subterranea) je samonikla afriška stročnica, ki se na veliko goji širom kontinenta. Je zelo raznolika poljščina z zelo različnimi morfološko-agronomskimi lastnostmi. Ta genetska raznolikost je najpomembnejša za njeno izboljšanje in določa tudi žlahtniteljske strategije in metode, ki jih je potrebno pri tem uporabiti. V raziskavi je bila ovrednotena raznolikost morfološko agronomskih lastnosti različnih akcesij bambare. Akcesija TVSu596 je pokazala največji odstotek kalivosti (100\%) in najkrajše obdobje do $50 \%$ cvetenja (40 dni), akcesija TVSu11 je imela največje število listov (146). Kakovostno ovrednotenje je odkrilo, da obstajajo razlike v morfološko-agronomskih lastnostih. Snovna analiza je pokazala, da so akcesije bogate na mineralih in da so razlike v vsebnostih le teh velike. Analiza glavnih komponent je odkrila, da je 83,37 \% celotne variabilnosti v morfoloških lastnostih in je pojasnjeno s prvimi tremi osnovnimi osmi. Lastnosti kot so število listov, dolžina peclja in število dni do $50 \%$ cvetenja prispevajo največji delež variabilnosti. Analiza združevanja je odkrila, da so akcesije porazdeljene v 4 skupine, ki jih priporočamo za uporabo pri vzgoji izboljšanih sort ali za zgodnje dozorevanje.

Ključne besede: Vigna subterranea; bambara; genetska raznolikost; analiza morfološko-agronomskih lastnoti; kemijska analiza

1 The Federal Polytechnic, Ile-Oluji, Nigeria

2 Corresponding author, e-mail: Yekeenolaidem@gmail.com

3 Federal College of Forestry, Ibadan, Nigeria 


\section{INTRODUCTION}

Vigna subterranea (L.) Verdc. popularly known as bambara groundnut is an indigenous African legume crop which is widely cultivated across the continent (Mkandawire, 2007). The seeds are used during the performance of funeral rites. It also possess medicinal properties, being chiefly used in the control of diarrhoea, skin rashes, and swollen jaw disease (Akpalu et al., 2013). V. subterranea is a highly diverse crop in terms of its size of seeds, colour of seeds, plant height, eye colour, eye patterns, hilum colour and patterns, and other morpho-agronomic characteristics (Ouedraogo et al., 2008; Akpalu et al., 2013). This genetic diversity is the basis for adaptation and survival of the species and makes it easy for them to adapt to changing of environmental conditions (Rao et al., 2002; Sevik et al., 2010). Adequate information about genetic diversity within crop species is essential for crop improvement as it determines methodologies to utilize in the improvement of the species (Aliyu et al., 2016). Hence, estimation of genetic variability of different traits is not only of economic importance but also crucial in cultivar development and improvement of any plant species (Odongo et al., 2015). This study therefore comparatively assessed the genetic variability in the morpho-agronomic traits and mineral elements present in seeds of seven colour variants of $V$. subterranea.

\section{MATERIALS AND METHODS}

The study was carried out within Federal College of Forestry, Ibadan, Nigeria. Seeds of seven accessions of V. subterranea (TVSu 119, TVSu 596, TVSu 182, TVSu 11, TVSu 367, TVSu 49 and TVSu 254) were utilized in the study. Germination test was conducted in a laboratory and the seedlings were later transplanted into modified plastic buckets arranged in a randomized complete block design (RCBD) with three replications. For the mineral elements determination, seeds of each accession were ground and $1 \mathrm{~g}$ of each was dry ashed for $5 \mathrm{~h}$ in a muffle furnace at $550{ }^{\circ} \mathrm{C}$ until a white residue with constant mass was obtained. The ash was digested with $3 \mathrm{M} \mathrm{HCl}$ and some of the mineral elements were investigated using atomic absorption spectrophotometer (AAS) (AOAC, 2003). For the evaluation of quantitative data, the analysis of variance (ANOVA), PCA and correlations were used.

\section{RESULTS AND DISCUSSION}

The result of elemental analysis is presented in Table 1. The result showed that 'TVSu119' is a good source of mineral elements though it is a little deficient in copper content, followed by 'TVSu596' which is rich in magnesium and potassium. This result is similar to that observed by Amarteifio et al. (2006).

Qualitative characteristics assessment result showed that two types of petiole pigmentation pattern (non-pigmented and slightly-pigmented) were observed. Leaf colour assessment result also showed the presence of three different types (dark green, pale green and green) of pigmentation patterns. The result of quantitative characters studied on the seven accessions is presented in Table 2 . Result showed that significant difference $(p \leq 0.01)$ exists in all characters among all the accessions studied. NL ranged from 67.80 to 146.00 . This contrasts with the result of Shegro et al. (2013). TLL ranged from $5.65 \mathrm{~cm}$ to $8.16 \mathrm{~cm}$ in 'TVSu49'. This is similar to the result of Shegro et al. (2013) but contrasted with the result of Ndiang et al. (2014).

TLW ranged from $2.38 \mathrm{~cm}$ to $4.72 \mathrm{~cm}$ in 'TVSu49'. This is similar to the result of Shegro et al. (2013). Petiole length ranges from $15.13 \mathrm{~cm}$ to $26.55 \mathrm{~cm}$ in 'TVSu49'. This contrasts with the result of Shegro et al. (2013) and Ndiang et al. (2014). DFF ranged from 40 days to 49 days. This is similar to the result of Brink et al. (2006) but contrasted with the result of Ouedraogo et al. (2008). D5F ranged from 40 days to 43 days. This is similar to the result of Brink et al. (2006). Number of seeds/plant ranged from 3.0 to 6.0. The low seed yield observed in these ac-

Table 1: Selected mineral elements studied on the analysed accessions of $V$. subterranea

\begin{tabular}{lllllll}
\hline Varieties & Accessions & $\mathrm{Ca}(\%)$ & $\mathrm{Mg}(\%)$ & $\mathrm{K}(\%)$ & $\mathrm{Fe}\left(\mathrm{mg} \mathrm{g}^{-1}\right)$ & $\mathrm{Cu}\left(\mathrm{mg} \mathrm{g}^{-1}\right)$ \\
\hline 1 & TVSu119 & 0.03 & 0.24 & 1.61 & 40.92 & 7.49 \\
2 & TVSu596 & 0.01 & 0.25 & 1.70 & 31.97 & 8.49 \\
3 & TVSu182 & 0.02 & 0.21 & 1.46 & 20.93 & 7.48 \\
4 & TVSu11 & 0.02 & 0.21 & 1.56 & 20.45 & 9.48 \\
5 & TVSu367 & 0.03 & 0.23 & 1.31 & 25.97 & 8.99 \\
6 & TVSu49 & 0.02 & 0.21 & 1.42 & 36.99 & 9.50 \\
7 & TVSu254 & 0.03 & 0.23 & 1.53 & 30.94 & 19.96 \\
\hline
\end{tabular}


Table 2: Quantitative characters studied on the analysed accessions of V. subterranea

\begin{tabular}{|c|c|c|c|c|c|c|c|c|c|c|}
\hline Accessions & GP & $\mathrm{HL}$ & SR & LN & NL & TLL & TLW & PL & DFF & D5F \\
\hline TVSu119 & $56^{\mathrm{e}}$ & $2.25^{\mathrm{bc}}$ & $3.20^{\mathrm{b}}$ & $9.70^{\mathrm{b}}$ & $67.80^{\mathrm{d}}$ & $6.28^{c}$ & $2.38^{\mathrm{c}}$ & $17.30^{\mathrm{bc}}$ & $49^{\mathrm{a}}$ & $51^{\mathrm{a}}$ \\
\hline TVSu596 & $100^{\mathrm{a}}$ & $4.26^{\mathrm{a}}$ & $8.96^{\mathrm{a}}$ & $17.92^{\mathrm{a}}$ & $92.20^{c}$ & $5.65^{c}$ & $2.50^{c}$ & $15.13^{\mathrm{d}}$ & $40^{\mathrm{d}}$ & $40^{\mathrm{f}}$ \\
\hline TVSu182 & $84^{\mathrm{b}}$ & $2.92^{b c}$ & $8.17^{\mathrm{a}}$ & $13.65^{\mathrm{ab}}$ & $126.90^{\mathrm{ab}}$ & $6.12^{\mathrm{c}}$ & $3.08^{\mathrm{b}}$ & $18.73^{b c}$ & $45^{\mathrm{b}}$ & $49^{b}$ \\
\hline TVSu11 & $60^{\mathrm{d}}$ & $2.84^{\mathrm{b}}$ & $4.23^{\mathrm{b}}$ & $13.07^{\mathrm{ab}}$ & $146.00^{\mathrm{a}}$ & $5.80^{c}$ & $2.86^{\mathrm{b}}$ & $19.33^{\mathrm{b}}$ & $40^{\mathrm{d}}$ & $43^{\mathrm{e}}$ \\
\hline TVSu367 & $56^{\mathrm{e}}$ & $2.44^{\mathrm{b}}$ & $3.95^{\mathrm{b}}$ & $5.78^{\mathrm{b}}$ & $106.10^{\mathrm{bc}}$ & $6.77^{\mathrm{b}}$ & $3.01^{\mathrm{b}}$ & $17.05^{\mathrm{cd}}$ & $41^{\mathrm{d}}$ & $44^{\mathrm{e}}$ \\
\hline TVSu49 & $79^{c}$ & $2.24^{\mathrm{bc}}$ & $4.31^{\mathrm{b}}$ & $8.08^{\mathrm{b}}$ & $85.50^{\mathrm{cd}}$ & $8.16^{a}$ & $4.72^{\mathrm{a}}$ & $26.55^{\mathrm{a}}$ & $40^{\mathrm{d}}$ & $46^{c}$ \\
\hline TVSu254 & $80^{c}$ & $1.17^{\mathrm{c}}$ & $4.47^{\mathrm{b}}$ & $8.52^{\mathrm{b}}$ & $122.10^{\mathrm{b}}$ & $8.07^{\mathrm{a}}$ & $2.98^{\mathrm{b}}$ & $19.18^{\mathrm{b}}$ & $43^{c}$ & $45^{\mathrm{cd}}$ \\
\hline Mean & 73.57 & 2.50 & 5.33 & 10.96 & 107.66 & 6.69 & 3.08 & 19.04 & 42.57 & 45.43 \\
\hline CV (\%) & 1.26 & 30.61 & 38.54 & 49.05 & 21.05 & 9.54 & 8.86 & 11.09 & 2.35 & 2.20 \\
\hline S.E.M \pm & 0.53 & 0.34 & 0.92 & 2.40 & 7.17 & 0.20 & 8.62 & 0.67 & 0.58 & 0.58 \\
\hline F Test & * & * & * & * & * & * & * & * & * & * \\
\hline L.S.D (0.05) & 1.62 & 0.99 & 2.66 & 6.96 & 20.25 & 0.57 & 0.24 & 1.89 & 1.75 & 1.75 \\
\hline
\end{tabular}

NOTE: GP-Germination percentage; HL-Hypocotyl length; SR-Seminal root length; LN-Lateral root number; NL-Number of leaves; TLL-Terminal leaflet length; TLW- Terminal leaflet width; PL-Petiole length; DFF-Days to first flowering; D5F-Days to $50 \%$ flowering. Means with the same letters are not significantly different from each other. ${ }^{*}$ : Significant at $5 \%$ level of probability. ${ }^{* *}$ : Significant at $1 \%$ level of probability.

Table 3: Correlations for morphological and yield characteristics of the analysed accessions of V. subterranea

\begin{tabular}{|c|c|c|c|c|c|c|c|c|c|c|}
\hline & GP & $\mathrm{HL}$ & SR & LN & NL & TLL & TLW & PL & DFF & D5F \\
\hline GP & 1 & & & & & & & & & \\
\hline HL & $0.45^{\star *}$ & 1 & & & & & & & & \\
\hline SR & $0.84^{\star *}$ & $0.73^{\star *}$ & 1 & & & & & & & \\
\hline $\mathrm{LN}$ & $0.64^{\star *}$ & $0.81^{\star \star}$ & $0.81^{\star *}$ & 1 & & & & & & \\
\hline NL & -0.01 & -0.06 & 0.15 & 0.17 & 1 & & & & & \\
\hline TLL & 0.01 & $-0.77^{\star *}$ & $-0.45^{\star *}$ & $-0.71^{\star *}$ & -0.15 & 1 & & & & \\
\hline TLW & 0.12 & -0.28 & -0.18 & $-0.40^{\star *}$ & -0.07 & $0.70^{\star *}$ & 1 & & & \\
\hline PL & -0.01 & $-0.42^{\star \star}$ & $-0.34^{*}$ & $-0.41^{\star *}$ & -0.04 & $0.70^{\star *}$ & $0.94^{* *}$ & 1 & & \\
\hline DFF & $-0.30^{*}$ & $-0.30^{*}$ & -0.19 & -0.12 & $-0.37^{\star}$ & -0.11 & $-0.42^{\star *}$ & -0.25 & 1 & \\
\hline D5F & $-0.39^{\star}$ & $-0.47^{\star \star}$ & $-0.34^{\star}$ & $-0.37^{\star}$ & $-0.30^{*}$ & 0.16 & 0.05 & 0.21 & $0.86^{\star \star}$ & \\
\hline
\end{tabular}

${ }^{*}$ Correlation is significant at the 0.05 level; ${ }^{* *}$ Correlation is significant at the 0.01 level.

cessions is similar to the result of Linnemann (1995). The co-efficient of variation (CV) ranged from $1.26 \%$ to $49.05 \%$. This showed that a high level of genetic diversity, exploitable by plant breeders, existed in the studied traits. Standard error of mean (SEM) ranges from 0.20 to 0.92 showing that the data is normally distributed with a steep bell-shaped curve. Pearson's correlation analysis (Table 3) showed that petiole length was strongly and positively correlated with TLW and TLL but negatively correlated with HL, LN and DFF. Positive correlation of germination percentage with SR, LN and HL indicated that accessions with higher germination percentage exhibited increased vegetative growth characteristics. While negative correlation with DFF and D5F indicated that accessions with higher germination percentage possessed lower days to first and $50 \%$ flowering.

The results of the PCA analysis are presented in Table 4 . The first five principal components explained about $98.2 \%$ of the total variation. The Eigen values ranged from 4.33 to 0.64 . Principal components axes 1 and 2 accounted for $43.33 \%$ and $25.84 \%$ variation respectively.

\section{CONCLUSION}

From the investigation, this study therefore submits that the germplasm displayed high genetic variability for the characteristics studied; hence they can still be im- 
Table 4: The Eigenvalues, proportion of variability and the phenotypic traits contributing to the first five Principal components of V. subterranea

\begin{tabular}{|c|c|c|c|c|c|}
\hline Item & PC1 & PC2 & PC3 & PC4 & PC5 \\
\hline Eigenvalues & 4.33 & 2.58 & 1.42 & 0.84 & 0.64 \\
\hline \%Variance per PC axes & 0.43 & 0.26 & 0.14 & 0.08 & 0.06 \\
\hline Cumulative Variance & 0.43 & 0.69 & 0.83 & 0.92 & 0.98 \\
\hline Morphological traits & \multicolumn{5}{|c|}{ Eigenvectors } \\
\hline Terminal leaflet length $(\mathrm{cm})$ & 0.38 & 0.29 & - & - & - \\
\hline Petiole length (cm) & 0.31 & 0.38 & 0.20 & - & - \\
\hline Days to $50 \%$ flowering & 0.26 & -0.35 & 0.39 & 0.33 & 0.31 \\
\hline Terminal leaflet width $(\mathrm{cm})$ & 0.26 & 0.47 & 0.21 & - & 0.34 \\
\hline Days to first flowering & - & -0.52 & 0.36 & 0.25 & - \\
\hline Lateral root number & -0.44 & - & - & - & - \\
\hline Hypocotyl length (cm) & -0.42 & - & - & -0.33 & 0.39 \\
\hline Seminal root length $(\mathrm{cm})$ & -0.40 & - & 0.30 & 0.27 & - \\
\hline Germination \% & -0.27 & 0.33 & 0.43 & 0.21 & -0.40 \\
\hline Number of leaves & - & - & -0.55 & 0.74 & - \\
\hline
\end{tabular}

NB: Only eigenvectors with values $\geq 0.20$ are presented.

proved genetically, as they can be useful to plant breeders who may be interested in specific traits and their variation within the species. The earliness in days to first and $50 \%$ flowering displayed by TVSu596 meant it could be utilized in the development of early-maturing varieties or cultivars. The study thus recommends further studies on the nutritional value of these accessions in order to evaluate their protein, carbohydrate and fat contents.

\section{ACKNOWLEDGEMENT}

The Vigna unguiculata accessions utilized in this study were obtained from Genetic Resources Centre, International Institute of Tropical Agriculture (IITA), Ibadan, Oyo State, Nigeria.

\section{REFERENCES}

Akpalu, M. M., Atubilla, I. A., \& Oppong-Sekyere, D. (2013). Accessing the level of cultivation and utilization of Bambara groundnut (Vigna subterranea (L.) Verdc.), in the Sumbrungu community of Bolgatanga, Upper East Region, Ghana. International Journal of Plant, Animal and Environmental Sciences,. 3(3), 68-75.

Aliyu, S., Massawe, F. \& Mayes, S. (2016). Genetic diversity and population structure of Bambara groundnut (Vigna subterranea (L.) Verdc.): synopsis of the past two decades of analysis and implications for crop improvement programmes.
Genetic Resources and Crop Evolution, 63, 925-943. https:// doi.org/10.1007/s10722-016-0406-Z

Amarteifio, J. O., Tibe, O. \& Njogu, R. M. (2006). The mineral composition of Bambara groundnut (Vigna subterranea (L.) Verdc.) grown in Southern Africa. African Journal of Biotechnology. 5 (23): 2408-2411, 2006.

Brink, M., Ramolemana, G. M. \& Sibuga, K. P. (2006). Vigna subterranea (L.) Verdc. In Brink, M. and Belay, G. (Editors). Plant Resources of Tropical African 1.Cereals and pulses. PROTA Foundation, Wageningen, Netherlands. Pp. 213218.

Linnemann, A. R. (1995). Phenological Development in Bambara groundnut (Vigna subterranea) transferred from 14 to 11 hour photoperiods. Journal of Agricultural Science. Cambridge Univ. Press. https://doi.org/10.1017/ S0021859600073111

Mkandawire, C. H., (2007): Review of Bambara groundnut ( Vigna subterranean (L.) Verdc.) Production in sub-Saharan Africa. Agricultural Journal, 2, 464-70.

Ndiang, Z., Bell, J. M., Fokam, P. E., Ouattara, B., Simo, C., \& Dibong, D. S. (2014). Agro-morphological variability in twelve Bambara groundnut (Vigna subterranea (L.)Verdc.) accessions in Cameroon. Sciences, Technologies \& Développement, 16, 38-45.

Odongo, F. O., Oyoo, M. E., Wasike, V., Owuoche, J. O., Karanja, L. \& Korir, P. (2015). Genetic diversity of Bambara groundnut (Vigna subterranea (L.) Verdc.) landraces in Kenya using microsatellite markers. African Journal of Biotechnology, 14(4), 283-291. https://doi.org/10.5897/AJB2014.14082

Ouedraogo, M., Ouédraogo, J. T., Tignere, J. B., Balma, D., Dabire, C. B. \& Konaté, G. (2008). Characterization and evaluation of accessions of Bambara groundnut [Vigna subterranea (L.) Verdcourt] from Burkina Faso. The Science 
of Nature, 5(2), 191-197. https://doi.org/10.4314/scinat. v5i2.42164

Rao, V. R., \& Hodgkin, T. (2002). Genetic diversity and conservation and utilization of plant genetic resources. Plant Cell Tissue Organ Culture, 68, 1-19. https://doi. org/10.1023/A:1013359015812

Sevik, H., Ayan, S., Turna, I., \& Yahyaoglu, Z. (2010). Genetic diversity among populations in Scotch pine (Pinus sylvestris
L.) seed stands of Western Black Sea Region in Turkey. African Journal of Biotechnology, 9(43), 7266-7272.

Shegro, A. G., Jansen Van Rensburg, W. S., \& Adebola, P. O. (2013). Assessment of genetic variability in Bambara groundnut (Vigna subterranea [L.] Verdc.) using morphological quantitative traits. Academia Journal of Agricultural Research, 1, 45-51. 